\title{
Warming and organic matter sources impact the proportion of dissolved to total activities in marine extracellular enzymatic rates
}

\author{
Federico Baltar ${ }^{1,2^{*}}$, Xosé Anxelu G. Morán ${ }^{3}$, Christian Lønborg ${ }^{4}$ \\ ${ }^{1}$ Department of Marine Science, University of Otago, PO Box 56, Dunedin 9054, New Zealand \\ ${ }^{2}$ NIWA/University of Otago Research Centre for Oceanography, PO Box 56, Dunedin 9054, \\ New Zealand \\ ${ }^{3}$ King Abdullah University of Science and Technology (KAUST), Red Sea Research Center \\ (RSRC), Thuwal, 23955-6900, Saudi Arabia \\ ${ }^{4}$ Australian Institute of Marine Science, PMB No 3, Townsville, Queensland 4810, Australia
}

Correspondence:

* Federico Baltar, Department of Marine Science, University of Otago, PO Box 56, Dunedin 9054, New Zealand

Email: federico.baltar@,otago.ac.nz, Phone: +64 34795621

ORCID ID : 0000-0001-8907-1494

Keywords: extracellular enzymatic activity; dissolved enzymes; warming; organic matter

Revised version of manuscript BIOG-D-17-00022

submitted to Biogeochemistry

March 2017 
1 Summary

Extracellular enzymatic activities (EEAs) are the rate-limiting step in the

3 degradation of organic matter. Extracellular enzymes can be found associated to cells

4 or dissolved in the surrounding water. The proportion of cell-free EEA constitutes in

5 many marine environments more than half of the total activity. This high proportion

6 causes an uncoupling between hydrolysis rates and the actual bacterial activity.

7 However, we do not know what factors control the proportion of dissolved relative to

8 total EEA, nor how this may change in the future ocean. To resolve this, we

9 performed laboratory experiments with water from the Great Barrier Reef (Australia)

10 to study the effects of temperature and dissolved organic matter sources on EEA and

11 the proportion of dissolved EEA. We found that warming increases the rates of

12 organic matter hydrolysis and reduces the proportion of dissolved relative to total

13 EEA. This suggests a potential increase of the coupling between organic matter

14 hydrolysis and heterotrophic activities with increasing ocean temperatures, although

15 strongly dependent on the organic matter substrates available. Our study suggests that

16 local differences in the organic matter composition in tropical coastal ecosystems will

17 strongly affect the proportion of dissolved EEA in response to ocean warming. 


\section{Introduction}

Heterotrophic bacterioplankton (including bacteria and archaea) play a key role in the cycling of matter in the ocean by transforming dissolved organic matter (DOM) into living particulate organic matter and $\mathrm{CO}_{2}$ (Azam \& Cho 1987). From the bulk DOM, these microbes preferentially utilize the high molecular weight fraction (Amon \& Benner 1996; Benner \& Amon 2015). Since only small molecules ( $<600 \mathrm{Da})$ can be directly transported across the cell membrane (Weiss et al. 1991), heterotrophic bacterioplankton need to cleave the high molecular weight molecules into smaller pieces before they can be transported into and used by the cells. To do so, aquatic microbes rely on the use of extracellular enzymes. Thus, extracellular enzymatic activities (EEA) are considered to be a rate limiting step in the degradation of organic matter (Hoppe et al. 2002).

EEA in the marine environments can be found attached to the cell wall or periplasmic space (i.e., cell-associated), or dissolved (i.e., cell-free) in the surrounding waters (Hoppe et al. 2002). Although there has been the perception that only cellassociated extracellular enzymes were of ecological significance (Chrost \& Rai 1993; Hoppe 1983; Hoppe et al. 2002; Rego et al. 1985; Someville \& Billen 1983); evidences are starting to accumulate strongly supporting a major role of cell-free EEA in the marine environment (Allison et al. 2012; Baltar et al. 2010; Baltar et al. 2013; Baltar et al. 2016a; Duhamel et al. 2010; Karner \& Rassoulzadegan 1995; Keith \& Arnosti 2001; Obayashi \& Suzuki 2008). A high proportion of dissolved relative to total EEA can cause a significant decoupling between the microbial processes occurring in a water mass and the actual cycling and/or hydrolysis of organic matter (Arnosti 2011; Baltar et al. 2010; Baltar et al. 2013; Karner \& Rassoulzadegan 1995). These active cell-free enzymes away from their sites (cells) can condition 
macromolecular DOM and organic surfaces for subsequent microbial growth (Hoppe 1984), suggesting a great potential ecological and biogeochemical importance of dissolved EEA, and emphasizing the need of further research on the factors controlling cell-free EEA.

Different potential sources of cell-free EEA have been suggested, including direct enzyme release from microbial cells in response to substrate, starvation, viral lysis, protist grazing and changes in cell permeability (Albertson et al. 1990; Alderkamp et al. 2007; Bochdansky et al. 1995; Chrost 1991; Karner \& Rassoulzadegan 1995). The resulting contribution of dissolved relative to total EEA will therefore depend not only on the response of individual cells to stimuli but also on interactions between organisms and how the environment impacts the lifetime of these free enzymes. Recently, a study in the Baltic Sea showed that the proportion of dissolved EEA was inversely related to temperature (Baltar et al. 2016a). These authors suggested that a decreased heterotrophic activity during months with lower temperature allowed for a longer lifetime of cell-free enzymes, thereby increasing the proportion of dissolved relative to total EEA. Still, there are many factors, besides temperature fluctuating between seasons (e.g. water mass advection, irradiance, microbial communities composition, organic matter quality and quantity), which might also affect the proportion of dissolved EEA and are difficult to account for in a seasonal field study.

Despite the importance and implications of cell-free EEA in marine environments, little is known about the controlling factors and/or how this will change as a response to future ocean warming. To resolve this question, we performed controlled laboratory experiments, to test the effect of temperature and selected DOM sources on EEAs and the relative importance of cell-free relative to total EEA. We 
studied the variation in EEAs of glycolytic enzymes [ $\beta$-glucosidase, BGase], a proteolytic enzyme [leucine aminopeptidase, LAPase]) and alkaline phosphatase [APase]), and in the proportion of dissolved relative to total LAPase, with water from the Great Barrier Reef (GBR) supplemented with DOM extracted from mangroves, seagrass or glucose, relative to unammended controls. These experiments were performed at three different temperatures (in situ, $-3^{\circ} \mathrm{C},+3^{\circ} \mathrm{C}$ ), aimed at capturing the ca. $+3{ }^{\circ} \mathrm{C}$ temperature increase expected to occur in ocean surface waters by the end of this century (Collins et al. 2013), without causing too much perturbation on DOMmicrobial interactions, as previously done in higher latitude environments (HueteStauffer et al. 2016; Huete-Stauffer et al. 2015).

Based on the notion that different enzymes are used to hydrolyze different substrates (carbohydrates, proteins, etc.) we hypothesized that differences in organic matter sources would change EEA rates. Although no information was available on how the proportion of dissolved EEA would be affected by different organic matter substrates, we hypothesized that different DOM sources would also change the relative proportion of cell-free EEA due to differences in the heterotrophic response. Based on the reported positive effect of temperature increases on extracellular enzymatic activities (Hollibaugh \& Azam 1983; Piontek et al. 2009; Piontek et al. 2010) we anticipated that warming would enhance the total EEA rates. Finally, we also hypothesized that increasing temperature would decrease the proportion of dissolved EEA due to an intensification of the heterotrophic metabolism and shorter lifetimes of EEA in warm compared to cold waters (Baltar et al. 2010; Baltar et al. 2016a). Also, higher EEA under high temperatures and subsequent less production and release of extracellular enzymes may be another reason for lower proportion of 
92 cell-free EEA. This is the first study on the effect of temperature on the proportion of

93 dissolved EEA under a controlled environmental setting.

Methods

\section{Experimental setup}

Surface seawater (5 m depth) from the Great Barrier Reef (GBR) off Townsville

99 (Australia), was collected the $18^{\text {th }}$ of October 2016 using a 25 L Acid cleaned Niskin

100 bottle and brought back to the laboratory from a coastal site of 20-30 m depth / $4 \mathrm{~km}$

101 from the coast away from direct human influence (Table 1). One part of the seawater

102 was filtered through pre-combusted $\left(450^{\circ} \mathrm{C}\right.$ for $\left.4 \mathrm{~h}\right) \mathrm{GF} / \mathrm{C}$ filters (nominal pore size

$1031.2 \mu \mathrm{m})$ to establish a microbial culture to be used in all experiments. The other part

104 of the seawater was gravity filtered through a dual-stage $(0.8 / 0.2 \mu \mathrm{m})$ filter cartridge

105 (Pall-Acropak Supor membrane), which had been pre-washed with Milli-Q (>10 L).

106 The seawater was thereafter used both as the control treatment and to dilute the DOM

107 obtained from a glucose solution, Mangrove and Seagrass leaves.

108 Fresh Mangrove (Rhizophora stylosa) and Seagrass leafs (Halodule uninervis) were

109 collected in Cleveland Bay $\left(19^{\circ} 13^{\prime} 05^{\prime \prime} \mathrm{S} 146^{\circ} 55^{\prime} 19^{\prime \prime} \mathrm{E}\right)$, Australia, brought back to the

110 laboratory and rinsed thoroughly with $0.2 \mu \mathrm{m}$-prefiltered surface water. The

111 Mangrove and Seagrass-derived DOM was thereafter extracted by adding approx. 25

$112 \mathrm{~g}$ of wet leaves to a glass bottle containing $1 \mathrm{~L}$ of $0.22 \mu \mathrm{m}$-filtered seawater. After 24

$113 \mathrm{~h}$ in the dark the water was filtered the water was filtered through a pre-combusted

114 GF/C filter and, then, through a dual-stage filter cartridge $(0.8 / 0.2 \mu \mathrm{m}$, Pall-Acropak

115 Supor membrane) to isolate the DOM fraction. The dissolved organic carbon (DOC)

116 of these solutions were then measured. 
117 Samples for the analysis of DOC were filtered through prewashed (250 mL Milli-Q

118 water) $0.2 \mu \mathrm{m}$ filters (Pall, Supor membrane Disc Filter) and collected in pre-

119 combusted $\left(450^{\circ} \mathrm{C}, 12\right.$ hours $)$ glass ampoules and preserved by adding $50 \mu \mathrm{L} 25 \%$

$120 \mathrm{H}_{2} \mathrm{PO}_{4}$. DOC concentrations were measured by high temperature combustion $\left(720^{\circ} \mathrm{C}\right)$

121 using a Shimadzu TOC-L carbon analyzer. Prior to analysis, CO2 remaining in the

122 acidified sample water was removed by sparging with $\mathrm{O}_{2}$ carrier gas. Three to five

123 replicate injections of $150 \mu \mathrm{L}$ were performed per sample. Concentrations were

124 determined by subtracting a Milli-Q blank and dividing by the slope of a daily

125 standard curve made from potassium hydrogen phthalate and glycine. Using the deep

126 ocean reference samples we obtained an average concentration of $43 \pm 1 \mu \mathrm{mol} \mathrm{L}{ }^{-1}$,

127 with the nominal DOC value provided by the reference laboratory (Prof. Hansell Lab)

128 being are $41-44 \mu \mathrm{mol} \mathrm{L}{ }^{-1}$.

129 The DOM sources were thereafter added to different 201 carboy's (seagrass,

130 mangrove, glucose) to reach a DOC enrichment of ca. $40 \mu \mathrm{mol}{ }^{-1}$ (corresponds to the

131 approximate seasonal build-up of in DOC in the GBR). Seagrass and Mangrove were

132 used due to their known contribution of organic material to tropical waters which

133 might change in response to anthropogenic perturbations (Duarte 2017). Glucose was

134 selected for comparison as an easily degradable DOC source. The GF/C filtered

135 microbial culture was thereafter added in a ratio of 1 part of microbial culture, to 9

136 parts of water (control, seagrass, mangrove, glucose).

137 The water was then distributed into acid-rinsed glass bottles $(500 \mathrm{ml})$ and incubated at

1383 different temperatures (in situ, $-3^{\circ} \mathrm{C},+3^{\circ} \mathrm{C}$ ), with 3 replicate bottles being analysed

139 for subsampling at Day $0,1,2,3$ and 4 . The incubations were performed at the

140 National Sea Simulator (SeaSim) of the Australian Institute of Marine Science

141 (AIMS), which is able to keep the temperature constant within a $0.1^{\circ} \mathrm{C}$ range. 
143 Measurement of Total and Dissolved extracellular enzymatic activity (EEA)

144 The hydrolysis of the fluorogenic substrate analogues 4-methylcoumarinyl-7-amide

145 (MCA)-L-leucine-7-amido-4-methylcoumarin, 4-methylumbelliferyl (MUF)- $\beta$-D-

146 glucoside and MUF-phosphate was analyzed to estimate potential activity rates of

147 leucine aminopeptidase (LAPase), $\beta$-glucosidase (BGase), and alkaline phosphatase

148 (APase), respectively (Hoppe 1983). The same procedure was followed as previously

149 described (Baltar et al. 2010; Baltar et al. 2013; Baltar et al. 2009). Briefly, EEA was

150 determined after substrate addition and incubation using a spectrofluorometer with a

151 microwell plate reader (Biotek Cytation 3 Imaging Multi-Mode Reader) at excitation

152 and emission wavelengths of 365 and $445 \mathrm{~nm}$, respectively. Samples (300 $\mu 1)$ were

153 incubated in the dark at the corresponding temperature (in situ, $-3^{\circ} \mathrm{C},+3^{\circ} \mathrm{C}$ ) for $1.5-3$

$154 \mathrm{~h}$. The increase in fluorescence over time was transformed into hydrolysis activity

155 using a standard curve established with different concentrations of the fluorochromes

156 MUF and MCA added to $0.2 \mu \mathrm{m}$ filtered sample water. A final substrate

157 concentration of $250 \mu \mathrm{mol}^{-1}$ was used to measure BGase activities, APase and

158 LAPase.

159 The total and the dissolved fraction of the LAPase EEA were distinguished as

160 previously described (Baltar et al. 2010; Baltar et al. 2013; Baltar et al. 2016a).

161 Briefly, raw seawater was used for total EEA; whereas for dissolved EEA, samples

162 were gently filtered through a low protein-binding $0.2 \mu \mathrm{m}$ Acrodisc Syringe filter

163 (Pall) for dissolved EEA following the protocol of (Kim et al. 2007). In the present

164 study, dissolved (cell-free) EEA is defined as the EEA recovered in the filtrate. Total

165 and dissolved EEA were determined on six technical replicate samples per treatment

166 and sampling point. 


\section{Statistical analysis}

169 The relation between temperature increase and the proportion of dissolved LAPase

170 was examined by means of regression analysis between temperature and the

171 proportion of dissolved LAPase on the final day of the experiment. A linear

172 regression model was fitted to the data and the slope was presented as an indication of

173 the relation between temperature and EEA. For calculating uncertainties in ratios,

174 error propagation was taken into account; SDs were calculated using a formula for the

175 propagation of error as described by (Bevington \& Robinson 2003) as follows:

$$
\Delta \mathrm{z} / \mathrm{z}=\sqrt{ }\left[\left((\Delta \mathrm{x})^{2} / \mathrm{x}\right)+\left((\Delta \mathrm{y})^{2} / \mathrm{y}\right)\right]
$$

177 where $\mathrm{z}$ is the percent abundance or the percent assimilation, which is equal to $\mathrm{x}$

178 divided by $\mathrm{y}$, as described above. $\Delta \mathrm{x}$ and $\Delta \mathrm{y}$ are the SDs associated with $\mathrm{x}$ and $\mathrm{y}$,

179 respectively. $\Delta z$ is the SD calculated for $z$. SDs were then converted to SEs for each

180 calculation

182 Results and Discussion

183 In situ inoculum conditions

184 Leucine aminopeptidase (LAPase) was the most active extracellular enzymatic

185 activity in the inoculum water used for this experiment (Table 1). LAPase was around

186 5- and 20-fold higher than alkaline phosphatase (APase) and $\beta$-glucosidase (BGase),

187 respectively. This higher magnitude of the activity of LAPase as compared to APase

188 and BGase is a recognized frequently observed characteristic in marine environments

189 (Hoppe et al. 2002). LAPase was selected as the target EEA to study the dynamic of

190 the proportion of dissolved relative to total EEA not only because LAPase is usually

191 the most active EEA in seawater, as also found in this study, but also because the 
192 proportion of dissolved APase and BGase have been shown to behave similarly to the

193 proportion of dissolved LAPase over large spatial and temporal scales (Baltar et al.

194 2010; Baltar et al. 2013; Baltar et al. 2016a). The proportion of dissolved LAPase,

195 sampled in October (austral spring), was $40.5 \pm 6 \%$ in the inoculum water. That

196 contribution is consistent with the $35-50 \%$ range of dissolved LAPase in the Baltic

197 Sea during spring-summer (Baltar et al. 2016a), but lower than the $65-100 \%$ range

198 observed during the rest of the year in the Baltic Sea and in the Atlantic Ocean (Baltar

199 et al. 2010; Baltar et al. 2013).

200

201 Response of total EEA to different organic matter sources

202 The inoculum water was diluted 1:10 with $0.22 \mu \mathrm{m}$-filtered seawater (see Methods for 203 more detail), causing the EEA rates to be below the detection limit at the beginning of 204 the experiments. However, the EEAs were already detectable after day 1 (Fig. 1).

205 APase was the EEA showing the fastest response among all the measured enzymes, 206 particularly in the mangrove treatment (Fig 1). This faster and stronger response of 207 APase to mangrove DOM compared with the other organic matter sources was 208 sustained during the whole experiment. This enhancement in APase could be 209 indicative of phosphorus limitation in the mangrove treatment since high APase 210 relative to LAPase has been suggested as indicative of P limitation (Sala et al. 2001).

211 Alternative, it is possible that this strong APase in the mangrove treatment could be

212 due to a strong increase in heterotrophic rates in response to highly palatable DOM

213 and/or linked to other processes such as cross-activation by nonpartner histidine

214 kinases, and/or the activation of genes involved in the regulation of elemental balance 215 during catabolic processes (Baltar et al. 2016b). 
216 BGase remained relatively low during the whole experiment, with the exception of

217 the mangrove treatment (Fig. 1). This higher BGase could be indicative of a

218 carbohydrate rich material (typical of land plants) or it could simply be due to a

219 higher heterotrophic growth rate. Although APase was the fastest EEA to react to

220 mangrove DOM, LAPase was the EEA reaching the highest rates (Fig. 1), consistent

221 with the highest LAPase found in the in situ inoculum water (Table 1). In contrast to

222 BGase, LAPase was increased in all the DOM treatments and control during the

223 length of the experiment, highlighting the generalist importance of this enzyme in the

224 growth of heterotrophic microbes.

Dissolved relative to total LAPase in response to different organic matter sources

227 A consistent pattern was observed for total LAPase over time, increasing in all

228 treatments (Fig. 2A). This increase in total LAPase was slightly higher in response to

229 glucose than in the control, increasing from 0 to 34 and $17 \mathrm{nmol} \mathrm{l}^{-1} \mathrm{~h}^{-1}$, respectively.

230 However, the strongest responses in total LAPase were found in the seagrass and

231 mangrove DOM treatments, increasing from 0 to 119 and $396 \mathrm{nmol} \mathrm{l}^{-1} \mathrm{~h}^{-1}$,

232 respectively. This stronger response observed in the seagrass and mangrove DOM

233 treatments relative to the glucose one could be indicative of a more nutritious nature

234 of the plant DOM containing not only carbohydrates but also other building blocks

235 and cofactors such as aminoacids, metal-ions, and vitamins, etc.

236 The dissolved LAPase followed a similar pattern to the total LAPase, showing a

237 stronger response in the mangrove DOM followed by the seagrass, glucose and

238 control (Fig. 2B). However, in contrast to the total LAPase, the dissolved LAPase

239 activities stopped increasing in most treatments (except mangrove) after day 3. 
240 Contrary the proportion of dissolved LAPase showed a decreasing with time (Fig.

$2412 \mathrm{C})$. This was more pronounced in the treatments with highest LAPase activities;

242 decreasing from 95 to $6 \%$ and from 74 to $14 \%$ in the seagrass and in the mangrove

243 treatment, respectively. This decrease contrasts the minor decrease in the glucose

244 treatment (from 33 to $25 \%$ ) and control (from 63 to 29\%), where the proportion of

245 dissolved LAPase was still $>25 \%$ at the end of the experiment. These results suggest

246 that changes in the sources of organic matter to tropical microbial bacterioplankton

247 communities will not only change the total EEA rates and the spectrum of EEA (due

248 to relative differences in the effect in different enzymes), but also the importance of

249 dissolved relative to total EEA.

251 Dissolved relative to total LAPase in response to temperature

252 The proportion of dissolved relative to total LAPase decreased consistently with time 253 in all treatments and temperatures (from 100 to 5\%), with higher decreases in the $\mathrm{M}$ 254 (from 74 to 5\%) and S (from 100 to 4\%) treatments, in turn characterized by higher 255 initial values of the proportion (Fig. 3). However, experimental warming noticeably 256 enhanced this decrease. Table 2 shows the effect of temperature on the final 257 proportions (day 4) at each treatment. Our results suggest that regardless of the source 258 of carbon, warming will likely result in a decrease in the fraction of dissolved EEA in

259 tropical coastal waters. This analysis indicated that the proportion of dissolved

260 LAPase dropped on average by 1.1 to $5 \%$ for every $1{ }^{\circ} \mathrm{C}$ increase depending on the 261 source of organic matter type supplied.

262 The results presented here are the first investigating the effect of temperature on the 263 proportion of dissolved EEA under a controlled environmental setting. These results 264 are consistent, with the seasonal relation observed between the proportion of 
265 dissolved LAPase, BGase and APase and temperature in a filed study in the Baltic

266 Sea, where the proportion of dissolved relative to total EEA decreased during spring-

267 summer (0-39\%) and increased (up to 100\%) during winter months (Baltar et al.

268 2016a). This seasonal pattern is also consistent with the observed increase in the

269 proportion of dissolved LAPase from 65 to $100 \%$ from the epipelagic to the

270 abyssopelagic layer of the Atlantic Ocean (Baltar et al. 2010), supporting the role of

271 temperature as the environmental driver affecting this proportion.

272 The above mentioned findings are also consistent with the negative effect of

273 temperature on the lifetime of extracellular enzymes (APase) in surface waters of the

274 Red Sea (Li et al. 1998), the extended lifetime of cell-free LAPase, APase and BGase

275 enzymes in Arctic waters (Steen \& Arnosti 2011), and with the long lifetimes (of

276 LAPase, APase and BGase) found in the deep as compared to the surface waters in

277 the Atlantic Ocean (Baltar et al. 2013).

278 These results suggest that the proportion of dissolved LAPase is tightly connected to

279 the heterotrophic activity level of the community, so that the higher the activity the

280 lower the proportion of dissolved LAPase. This could be explained by two likely

281 causes. One plausible explanation is that the decrease in the community heterotrophic

282 rates would also mean a decrease in the degradation/consumption of free enzymes,

283 allowing for extended lifetimes of free enzymes (Baltar et al. 2016a). This option

284 gives a greater weight to temperature than to other factors, suggesting that the higher

285 the temperature the shorter the lifetime of free enzymes and the proportion of

286 dissolved EEA. An alternate explanation could be that actively growing microbes

287 would rely more closely on cell-attached rather than cell-free EEA (i.e., produce more

288 new enzymes which will be more frequently found, at least initially, attached to the

289 cells), causing the proportion of dissolved EEA to decrease more strongly under 
290 slower growth (conditions). This second option would also mean that the organic

291 matter substrates that most stimulate the heterotrophic activity of microbes will

292 thereby be the ones showing the largest decrease in the proportion of dissolved

293 relative to total LAPase. This second explanation becomes particularly important in

294 the context of this study, where most particles were initially removed by filtration,

295 since free-living microbes tend to show a tight hydrolysis-uptake coupling, whereas

296 particle-attached microbes tend to show a loose hydrolysis-uptake coupling producing

297 a lot of cell-free enzymes (Karner \& Herndl 1992; Smith et al. 1992; Vetter et al.

298 1998). Thus, the absence (or strongly reduced number) of large particles and the

299 availability of substrate would favour a pronounced decrease in the proportion of

300 dissolved LAPase.

301 The results obtained in this study together with recent reports suggest that the

302 proportion of dissolved relative to total LAPase, and thereby the coupling between

303 hydrolysis of organic matter and other microbial heterotrophic processes (such as

304 production, respiration, etc.), depends not only on temperature but also on the organic

305 matter substrates available. Overall, the proportion of dissolved relative to total

306 LAPase will depend on the balance between "passive" accumulation of free enzymes

307 (controlled in turn by the balance between production and consumption of free

308 enzymes in response to changes in temperature and in community heterotrophic rates)

309 and "active" production of cell-attached enzymes in response to organic matter inputs.

311 Conclusions

312 To our knowledge this study is the first to determine the effect of temperature and

313 different DOM sources on the proportion of dissolved relative to total EEA. Our

314 results suggest that increased temperature will not only affect the total enzymatic 
315 activity (increasing the hydrolysis of organic matter) but will also alter the structuring

316 of EEA by reducing the proportion of dissolved relative to total EEA. Thus, these

317 results suggest that the decoupling between the hydrolysis of the organic matter and

318 the actual growth of heterotrophic microbes (as well as the magnitude of the

319 conditioning of macromolecular DOC and organic surfaces for microbial growth by

320 dissolved enzymes away from the source cells), will likely be reduced with increasing

321 ocean temperatures. Moreover, this decrease will greatly depend on the organic matter

322 substrates available, and therefore on present and future changes in the structure of

323 tropical coastal ecosystems (i.e., health and cover of mangrove, seagrass, etc.).

\section{Acknowledgments}

326 The authors would like to thank the SeaSim team at AIMS for the help with setting up

327 the experiments. The study was co-financed by the AIMS visiting fellowship program

328 as part of the capability development fund (CDF). F. Baltar was supported by a

329 University of Otago Research Grant.

331 Conflict of Interest

332 The authors declare that they have no conflict of interest. 
333

334 Albertson NH, Nystrom T, Kjelleberg S (1990) Macromolecular-synthesis during

\section{References} recovery of the marine Vibrio sp. S14 from starvation. Journal of General Microbiology 136: 2201-2207 Alderkamp AC, Rijssel Mv, Bolhuis H (2007) Characterization of marine bacteria and the activity of their enzyme systems involved in degradation of the algal storage glucan laminarin. FEMS Microbiology Ecology 59: 108-117

Allison SD, Chao Y, Farrara JD, Hatosy S, Martiny A (2012) Fine-scale temporal variation in marine extracellular enzymes of coastal southern California. Frontiers in microbiology 3: 301

Amon RMW, Benner R (1996) Bacterial utilization of different size classes of dissolved organic matter. Limnol. Oceanogr. 41: 41-51 Arnosti C (2011) Microbial extracellular enzymes and the marine carbon cycle. Annual Review of Marine Science 3: 401-425

Azam F, Cho BC (1987) Bacterial utilization of organic matter in the sea. In: Ecology of microbial communities. Cambridge University Press, Cambridge. p 261281

Baltar F, Arístegui J, Gasol JM, Sintes E, Aken HMv, Herndl GJ (2010) High dissolved extracellular enzymatic activity in the deep central Atlantic Ocean. Aquatic Microbial Ecology 58: 287-302

Baltar F, Arístegui J, Gasol JM, Yokokawa T, Herndl GJ (2013) Bacterial Versus Archaeal Origin of Extracellular Enzymatic Activity in the Northeast Atlantic Deep Waters. Microbial ecology 65(2): 277-288

Baltar F, E. Sintes, H. Van Aken, J. M. Gasol, J. Arístegui, Herndl GJ (2009) Prokaryotic extracellular enzymatic activity in relation to biomass production and 
358

359

360

361

362

363

364

365

366

367

368

369

respiration in the meso- and bathypelagic waters of the (sub)tropical Atlantic.

Environmental Microbiology 11(8): 1998-2014

Baltar F, Legrand C, Pinhassi J (2016a) Cell-free extracellular enzymatic activity is linked to seasonal temperature changes: a case study in the Baltic Sea. Biogeosciences

$$
\text { 13(9): 2815-2821 }
$$

Baltar F, Lundin D, Palovaara J, Lekunberri I, Reinthaler T, Herndl GJ, Pinhassi J (2016b) Prokaryotic responses to ammonium and organic carbon reveal alternative $\mathrm{CO} 2$ fixation pathways and importance of alkaline phosphatase in the mesopelagic North Atlantic. Frontiers in Microbiology 7: 1670

Benner R, Amon RM (2015) The size-reactivity continuum of major bioelements in the ocean. Annual review of marine science 7: 185-205

Bevington PR, Robinson DK (2003) Data reduction and error analysis for the physical sciences. McGraw Hill, San Francisco, CA

Bochdansky AB, Puskaric S, Herndl GJ (1995) Influence of zooplankton grazing on free dissolved enzymes in the sea. Mar. Ecol. Prog. Ser. 121: 53-63

Chrost RJ (1991) Environmental control of the synthesis and activity of aquatic microbial ectoenzymes. In: Microbial enzymes in aquatic environments.

Brock/Springer series on contemprorary bioscience. Springer Verlag, New York. $p$ 29-59

Chrost RJ, Rai H (1993) Ectoenzyme activity and bacterial secondary production in nutrient-improverished and nutrient-enriched mesocosms. Microbolial Ecology 25: $131-150$

Collins M, Knutti R, Arblaster J, Dufresne J-L, Fichefet T, Friedlingstein P, Gao X, Gutowski W, Johns T, Krinner G (2013) Long-term climate change: projections, commitments and irreversibility. In: T.F. Stocker DQ, G.-K.Plattner, M.Tignor, S. 
383 K.Allen, J.Boschung, A.Nauels, Y.Xia, V.Bex, and P.M.Midgley (ed) Climate

384 Change 2013, The Physical Science Basis .Contribution of Working Group I to the

385 Fifth Assessment Report of the Intergovernmental Panel on Climate Change.

386 Cambridge University Press, NewYork. p 1029-1136

387 Duarte CM (2017) Reviews and syntheses: Hidden Forests, the role of vegetated

388 coastal habitats on the ocean carbon budget. Biogeoscience 14: 301-310

389 Duhamel S, Dyhrman ST, Karl DM (2010) Alkaline phosphatase activity and

390 regulation in the North Pacific Subtropical Gyre. Limnology and Oceanography

$391 \quad 55(3): 1414-1425$

392 Hollibaugh JT, Azam F (1983) Microbial degradation of dissolved proteins in

393 seawater. Limnol. Oceanogr. 28: 1104-1116

394 Hoppe H Relations between bacterial extracellular enzyme activities and

395 heterotrophic substrate uptake in a brackishwater environment. In: 2. Colloque

396 International de Bacteriologie Marine, Brest (France), 1-5. 1984.

397 Hoppe H-G (1983) Significance of exoenzymatic activities in the ecology of brackish

398 water: measurements by means of methylumbelliferyl-substrates. Mar. Ecol. Prog.

399 Ser. 11: 299-308

400 Hoppe H-G, Arnosti C, Herndl GJ (2002) Ecological significance of bacterial

401 enzymes in the marine environment. In: Burns RG \& Dick RP (eds) Enzymes in the

402 environment: activity, ecology, and applications. Marcel Dekker, Inc., New York. p

$403 \quad 73-108$

404 Huete-Stauffer TM, Arandia-Gorostidi N, Alonso-Sáez L, Morán XAG (2016)

405 Experimental Warming Decreases the Average Size and Nucleic Acid Content of

406 Marine Bacterial Communities. Frontiers in microbiology 7: 730 
407 Huete-Stauffer TM, Arandia-Gorostidi N, Díaz-Pérez L, Moran XAG (2015)

408 Temperature dependences of growth rates and carrying capacities of marine bacteria

409 depart from metabolic theoretical predictions. FEMS microbiology ecology 91(10):

$410 \quad$ fiv111

411 Karner M, Herndl GJ (1992) Extracellular enzymatic activity and secondary

412 production in free-living and marine snow associated bacteria. Mar. Biol. 113: 341-

$413 \quad 347$

414 Karner M, Rassoulzadegan F (1995) Extracellular enzyme activity: indications for

415 high short-term variability in a coastal marine ecosystem. Microb. Ecol. 30: 143-156

416 Keith SC, Arnosti C (2001) Extracellular enzyme activity in a river-bay-shelf transect:

417 variations in polysaccharide hydrolysis rates with substrate and size class. Aquatic

418 Microbial Ecology 24: 243-253

419 Kim C, Nishimura Y, Nagata T (2007) High potential activity of alkaline phosphatase

420 in the benthic nepheloid layer of a large mesotrophic lake: implications for

421 phosphorus regeneration in oxygenated hypolimnion. Aquatic Microbial Ecology 49:

$422 \quad 303-311$

423 Li H, Veldhuis MJW, Post AF (1998) Alkaline phosphatase activities among

424 planktonic communities in the northern Red Sea. Mar. Ecol. Prog. Ser. 173: 107-115

425 Obayashi Y, Suzuki S (2008) Adsorption of extracellular proteases in seawater onto

426 filters during size fractionation. Journal of Oceanography 64: 367-372

427 Piontek J, Haendel N, Langer G, Wohlers J, Riebesell U, Engel A (2009) Effects of

428 rising temperature on the formation and microbial degradation of marine diatom

429 aggregates. Aquat Microb Ecol 54: 305-318 
430 Piontek J, Lunau M, Händel N, Borchard C, Wurst M, Engel A (2010) Acidification

431 increases microbial polysaccharide degradation in the ocean. Biogeosciences 7: 1615-

$432 \quad 1624$

433 Rego JV, Billen G, Fontigny A, Someville M (1985) Free and attached proteolytic

434 activity in water environments. Marine Ecology Progress Series 21: 245-249

435 Sala MM, Karner M, Arin L, Marrasé C (2001) Measurement of ectoenzyme

436 activities as an indication of inorganic nutrient imbalance in microbial communities.

437 Aquatic Microbial Ecology 23: 301-311

438 Smith DC, Simon M, Alldredge AL, Azam F (1992) Intense hydrolytic enzyme

439 activity on marine aggregates and implications for rapid particle dissolution. Nature

440 359: 139-142

441 Someville M, Billen G (1983) A method for determining exoproteolytic activity in

442 natural waters. Limnology and Oceanography 28: 190-193

443 Steen AD, Arnosti C (2011) Long lifetimes of beta-glucosidase, leucine

444 aminopeptidase, and phosphatase in Arctic seawater. Mar. Chem. 123(1-4): 127-132

445 Vetter YA, Deming JW, Jumars PA, Krieger-Brockett BB (1998) A predicitive model

446 of bacterial foraging by means of freely released extracellular enzymes. Microb. Ecol.

$447 \quad 36: 75-92$

448 Weiss M, Abele U, Weckesser J, Welte W, Schiltz E, Schulz GE (1991) Molecular

449 architecture and electrostatic properties of bacterial porin. Science 254: 1627-1630 
451 Table 1. Location, physicochemical characteristics and extracellular enzymatic 452 activities of the inoculum water used to setup the experiment. APase: alkaline 453 phosphatase, BGase: $\beta$-glucosidase, LAPase: leucine aminopeptidase.

454

\begin{tabular}{|c|c|}
\hline Latitude (S) & $19^{\circ} 13^{\prime} 6.60^{\prime \prime}$ \\
\hline Longitude (E) & $147^{\circ} 8^{\prime} 21.24^{\prime \prime}$ \\
\hline Temperature $\left({ }^{\circ} \mathrm{C}\right)$ & $27.7^{\circ} \mathrm{C}$ \\
\hline Salinity & 35.5 \\
\hline APase $\left(\mathrm{nmol} \mathrm{l}^{-1} \mathrm{~h}^{-1}\right)$ & 4.01 \\
\hline BGase $\left(\mathrm{nmol} \mathrm{l}^{-1} \mathrm{~h}^{-1}\right)$ & 0.90 \\
\hline LAPase $\left(\right.$ nmol 1-1 $\left.\mathrm{h}^{-1}\right)$ & 19.29 \\
\hline Dissolved LAPase $\left(\mathrm{nmol} \mathrm{l}^{-1} \mathrm{~h}^{-1}\right)$ & 7.81 \\
\hline Proportion of dissolved LAPase (\%) & 40.5 \\
\hline Bacterial abundance $\left(\right.$ cell $\left.\mathrm{ml}^{-1}\right)$ & $4.18 \times 10^{5}$ \\
\hline DOC $\left(\mu \mathrm{mol} \mathrm{l}^{-1}\right)$ & 84 \\
\hline
\end{tabular}

455

456 
Table 2. Linear regression model results for the proportion of dissolved LAPase versus temperature on the final ratios (day 4) at each treatment.

459

460

\begin{tabular}{|l|l|l|l|l|l|}
\hline & Slope $\left(\%{ }^{\circ} \mathrm{C}^{-1}\right)$ & $\mathrm{SE}$ & $\mathrm{r} 2$ & $\mathrm{p}$ & $\mathrm{n}$ \\
\hline Control & -5.07 & 1.62 & 0.91 & 0.07 & 3 \\
\hline Glucose & -1.53 & 0.08 & 1.00 & 0.03 & 3 \\
\hline Mangrove & -2.48 & 0.18 & 0.99 & 0.02 & 3 \\
\hline Seagrass & -1.11 & 0.30 & 0.93 & 0.07 & 3 \\
\hline
\end{tabular}

461

462

463

464 
Figure legends

466

467 Figure 1. Mean ( \pm SE) temporal variability of total extracellular enzymatic activities

468 (APase: alkaline phosphatase, BGase: $\beta$-glucosidase, LAPase: leucine

469 aminopeptidase) in the different dissolved organic matter treatments and controls. C:

470 control, G: glucose, M: mangrove, S: seagrass, t1: day 1, t2: day 2, t3: day3, t4: day 4. 471

472 Figure 2. Mean ( \pm SE) temporal evolution of total LAPase (A), dissolved LAPase (B)

473 and the proportion of dissolved relative to total LAPase $(\mathrm{C})$ in response to the

474 different dissolved organic matter treatments and controls. C: control, G: glucose, M:

475 mangrove, S: seagrass.

476

477 Figure 3. Mean $( \pm S E)$ temperature effect on total LAPase (A-D) and the proportion

478 of dissolved to total LAPase dissolved LAPase (E-H) during the incubations in the

479 control $(\mathrm{A}, \mathrm{E})$ and in response to glucose $(\mathrm{B}, \mathrm{F})$, dissolved organic matter from

480 mangrove $(C, G)$ and from seagrass $(D, H)$. 


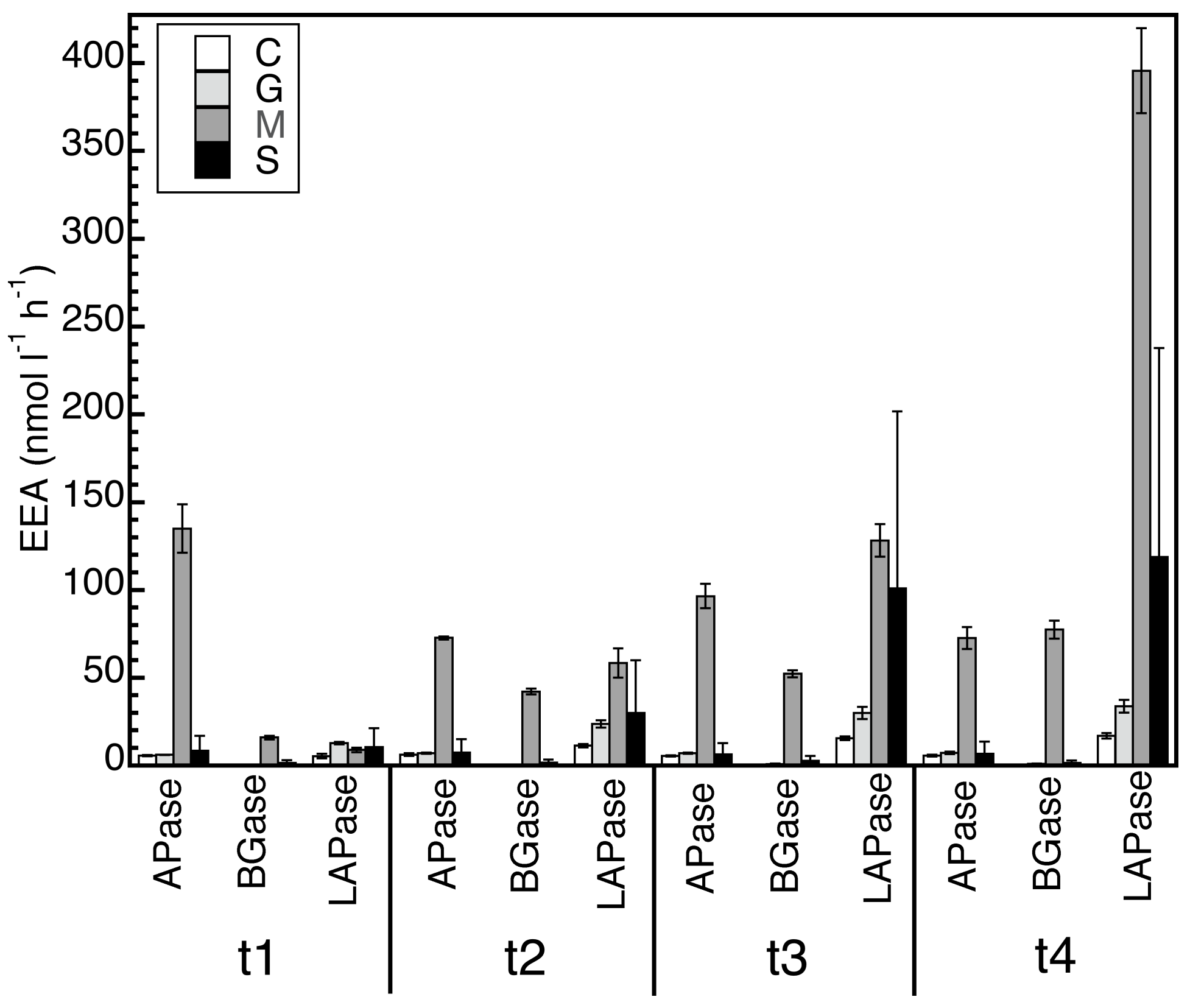


Total LAPase

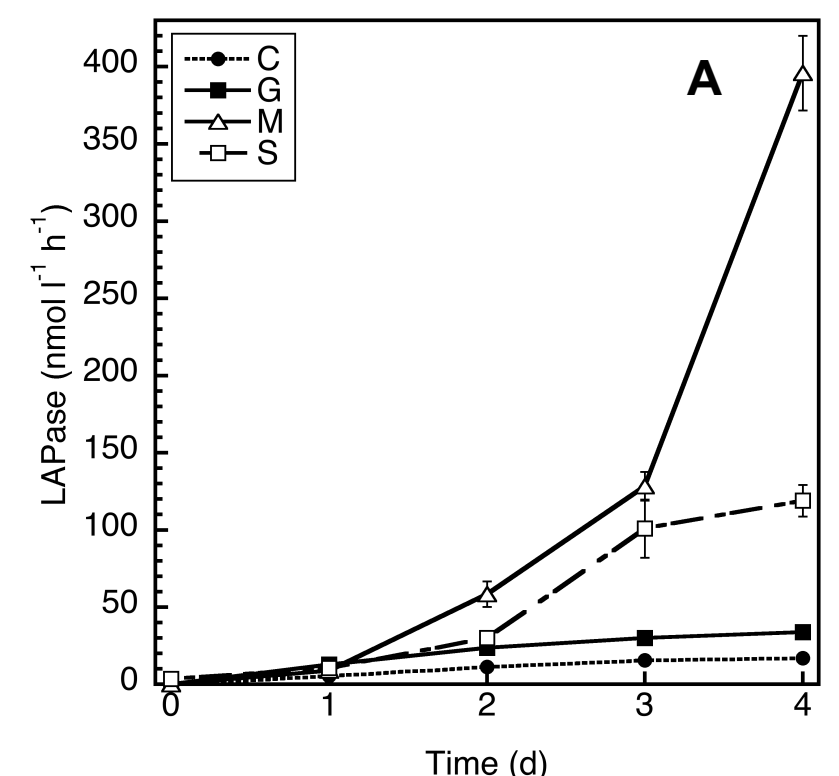

Dissolved LAPase

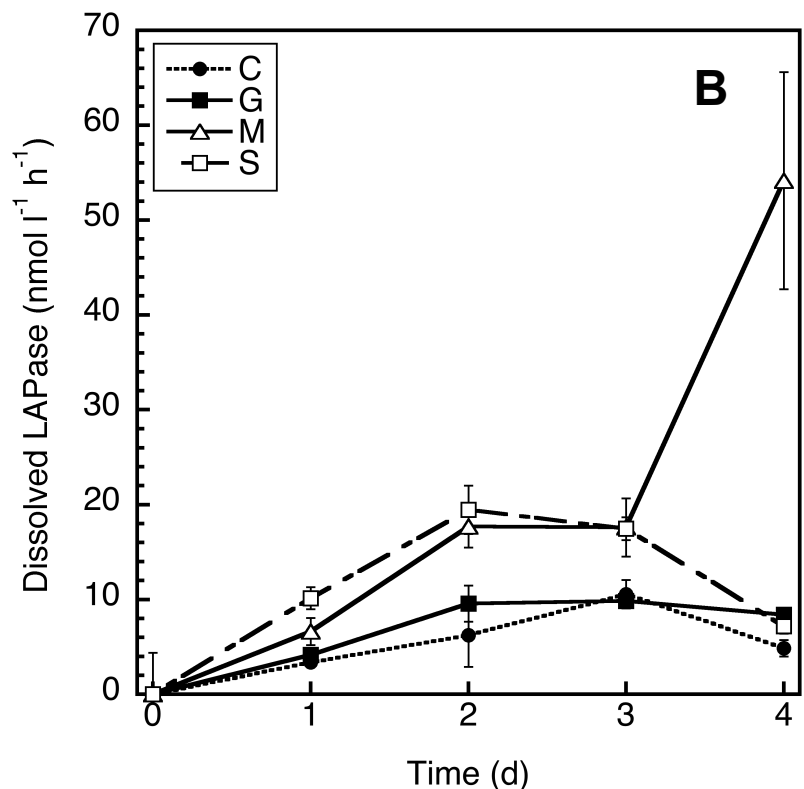

\% Dissolved LAPase

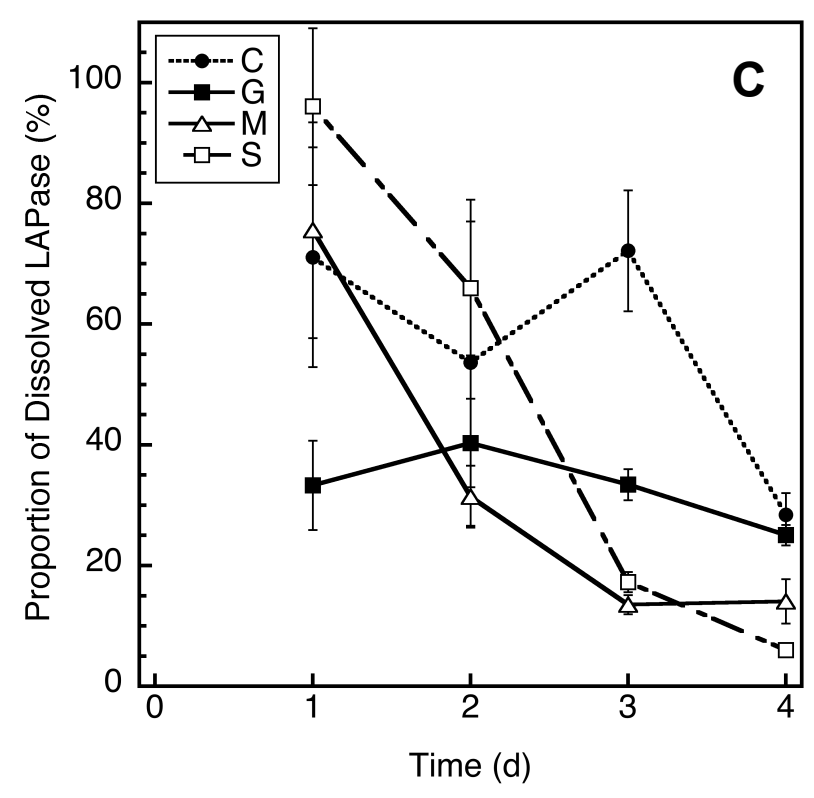



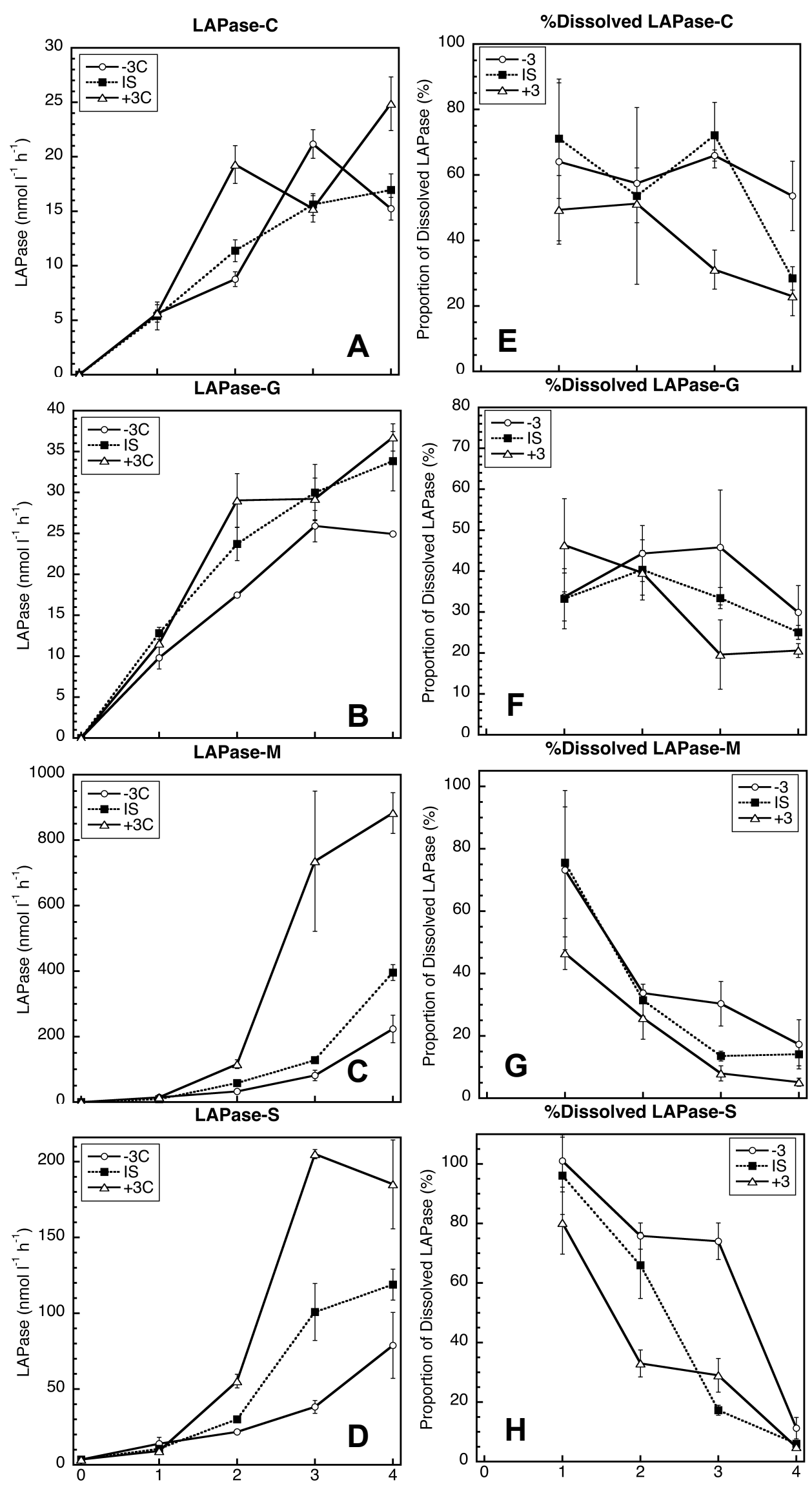

Time (d)

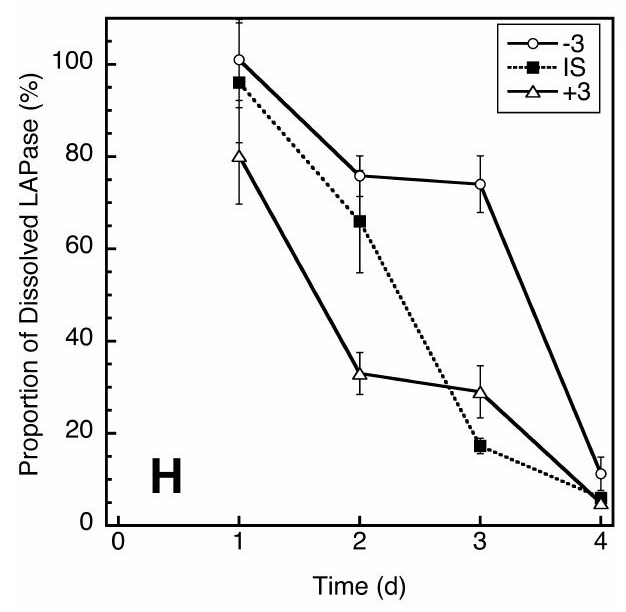

